\title{
Comparison of graphical analyses for maize genetic experiments: Application of biplots and polar plot to line $x$ tester design
}

Fatih Kahriman $^{1 *}$, Cem Ömer Egesel ${ }^{2}$, Gül Ebru Orhun ${ }^{3}$, Baris Alaca ${ }^{1}$, and Fatma Avci ${ }^{1}$

\section{ABSTRACT}

Graphical techniques have become important tools to show results of maize (Zea mays L.) breeding experiments in current literature. The present study compared different graphical techniques to determine the best parental lines and cross combinations for yield and kernel quality traits in maize breeding experiments. We measured single plant yield, protein content, oil content, carotenoid content, oleic acid, and linoleic acid in a $5 \times 2$ line $\times$ tester design. Genotype + genotype $\times$ environment $(\mathrm{GE})$ biplot, principal component analysis (PCA) biplot, and polar plot were used to analyze data and compare them with conventional line $x$ tester analysis. In the conventional analysis, parents with high means and positive general combining ability (GCA) values were A680 and HYA for single plant yield, IHP for protein content, IHO and HYA for oil content, A680 and Q2 for carotenoid content, IHP for oleic acid content, and A680 for linoleic acid content. The B73 tester exhibited positive GCA values for most investigated traits. The HYA $\times$ B73 combination was the best cross in terms of single plant yield, protein, and oil contents. Results showed that biplot methods had both advantages and disadvantages. The PCA biplots can be used alone while the GGE biplot and polar plots are both useful for combining ability, heterosis, and gene action analysis in a line $\times$ tester design. Overall, graphical analysis results were very similar to conventional analysis. Consequently, it was assumed that the graphical methods used could be useful to analyze/present data from maize breeding experiments carried out with a line $\times$ tester design.

Key words: Biplots, carotenoid, fatty acid, maize, oil, protein, Zea mays.

${ }^{1}$ Çanakkale Onsekiz Mart University, Department of Field Crops, 17020 Çanakkale, Turkey.

"Corresponding author (fkahriman@hotmail.com).

${ }^{2}$ Çanakkale Onsekiz Mart University, Department of Agricultural Biotechnology, 17020 Çanakkale, Turkey.

${ }^{3}$ Çanakkale Onsekiz Mart University, Bayramiç Vocational College, 17020 Çanakkale, Turkey.

Received: 23 November 2015.

Accepted: 20 May 2016.

doi:10.4067/S0718-58392016000300004

\section{INTRODUCTION}

High yield is one of the main breeding goals in maize (Zea mays L.) Substantial work has been carried out to develop both yield and quality traits (Egesel et al., 2013). The main traits to improve maize kernel quality are protein and oil content. Normal maize genotypes contain $8 \%$ to $11 \%$ protein and $3.0 \%$ to $5.5 \%$ oil (Langade et al., 2013). Minor components, such as fatty acids and carotenoids, are also desirable traits along with the major components. The high content of unsaturated fatty acid in maize oil is the main factor in its high quality (Ozcan, 2009). Thus, increasing oleic acid in maize oil can promote its use for food and industrial purposes (Mittelmann et al., 2003; Pollak and Scott, 2005). Carotenoids are major antioxidant biomolecules in maize grain; increasing carotenoid content is one of the main objectives of bio-fortification (de Almeida Rios et al., 2014). Numerous breeding experiments have been conducted in different countries to develop the abovementioned traits, and breeding materials have been evaluated using different breeding designs.

Crop breeders seek the most appropriate materials for breeding and the way to present clearly the results of experimental scientific studies. Graphical techniques have become important tools to demonstrate such results from maize breeding experiments in current literature. The most used breeding designs are bi-parental, multiple crosses, test crosses, line $\times$ tester, and diallel designs (Nduwumuremyi et al., 2013). The main objective of these designs is to determine the combining abilities of experimental crosses and parental lines besides understanding the heredity of the investigated traits. Line $\times$ tester analysis $(1 \times t)$, which is a modified version of top cross design, is commonly used (Sharma, 2006). The most important advantage of this method is that it enables evaluation with less experimental materials compared to other designs. On the other hand, heterosis analyses can also be carried out with this method. The $1 \mathrm{x}$ t design has been used in studies about yield and agronomic traits (Turgut, 2003; Elmyhum, 2013; Amin et al., 2014), as well as in research aimed at kernel quality (Bekele and Rao, 2013; Mahesh et al., 2013).

Although breeding designs have different applications, their common problem is the visual presentation of results. Researchers look for alternatives to conventional methods in terms of comprehensibility and visual quality. Various graphical methods have been developed. Biplots are the leading choice for visualizing the results of breeding experiments. The genotype + genotype $x$ environment (GGE) biplot analysis is the main method to demonstrate the combining abilities of parents and crosses. Thus, 
this method has commonly been used to evaluate combining abilities in maize breeding experiments in recent years (Mostavi et al., 2012; Badu-Apraku et al., 2013; Ruswandi et al., 2015). Additionally, the canonical discriminant analysis with yypothesis error (CDA-HE) plot has also been used to evaluate genotypes in breeding experiments for investigated traits (Egesel et al., 2011). Polar plot is a new method for heterosis analysis and gene action analysis (Lisec et al., 2011). Another alternative method, a multivariate graphical method known as principal component analysis (PCA) biplot, has not yet been used to establish combining abilities in breeding experiments. Hence, there is a need to compare different graphical methods to show results of maize breeding experiments, such as the $1 \mathrm{x}$ t design.

Therefore, our aim was to investigate the combining abilities of parents and crosses in $1 \times \mathrm{t}(5 \times 2$ designs $)$ for plant yield and several kernel quality traits. We compared GGE biplot and PCA biplot to visualize the combining abilities in an $1 \times \mathrm{t}$ design. Furthermore, the study aimed to determine the heterosis values of crosses and state the advantages and disadvantages of different graphical methods. Polar plots were applied to the heterosis analysis and gene action analysis was performed for the investigated traits.

\section{MATERIALS AND METHODS}

A breeding set was used in this study, which contained 10 crosses, 5 female parents, and 2 testers (Table 1). For the female parents, IHO has high oil content, IHP has high protein content, and HYA has high values of both oil and protein contents. The Q2 line has opaque kernel structure and the A680 line has high oleic acid content. The B73 and Mo17 testers are commonly used as parental lines and are known as representatives of the Reid Yellow Dent and Lancaster Sure Crop heterotic groups, respectively. This set was generated in 2012.

The evaluation trial was carried out in Dardanos Agricultural Research Station, Çanakkale Onsekiz

Table 1. Maize genotypes used in the study.

\begin{tabular}{ll}
\hline Parents and Crosses & \multicolumn{1}{c}{ Name } \\
\hline Testers & B73, Mo17 \\
Female Parents & A680, HYA, IHO, IHP, Q2 \\
Crosses & A680×B73, A680×Mo17, HYA×B73, HYA×Mo17, \\
& IHO×B73, IHO×Mo17, \\
& IHP×B73, IHP×Mo17, Q2×B73, Q2×Mo17 \\
\hline
\end{tabular}

Mart University, Çanakkale, Turkey, and was based on a randomized block design with three replicates. Each genotype was planted in two-row plots with a plot driller in May 2013. Seeds were planted at a distance of $70 \times$ $20 \mathrm{~cm}$ apart with a sowing density of 71400 plants ha-1. Fertilization was based on soil analysis and $180 \mathrm{~kg} \mathrm{ha}^{-1}$ pure $\mathrm{N}$ was applied as fertilizer (ENTEC perfect, EuroChem Agro $\mathrm{GmbH}$, Mannheim, Germany). Plots were watered by drip irrigation method according to plant needs. Hand pollination was used to prevent any possible pollen contamination between genotypes, and at least six ears were pollinated by hand for kernel quality analysis. Six open-pollinated and six hand-pollinated ears were harvested after physiological maturity and stored for yield determination and quality analysis, respectively.

To determine yield, open-pollinated ears were shelled and weighed on a laboratory balance. For quality analysis, hand-pollinated ears were shelled and ground in a laboratory mill (Pulverisette 14, Fritsch, Idar-Oberstein, Germany) with a $0.5 \mathrm{~mm}$ sieve. Protein and oil contents of the samples were determined with a near infrared reflectance (NIR) spectrophotometer (SpectraStar 2400D, Unity Scientific, USA). Carotenoid content was quantified spectrophotometrically according to Rodriguez-Amaya and Kimura (2004). Carotenoid was determined at $450 \mathrm{~nm}$ with an ultraviolet-visible (UV-VIS) spectrophotometer (T60, PG Instruments Ltd., Lutterworth, UK). Oleic and linoleic acid contents were determined with an NIR spectrophotometer (SpectraStar 2400D, Unity Scientific, Waltham, Massachusetts, USA). To do this, $50 \mathrm{~g}$ of ground samples were suspended in diethyl ether overnight. The ether was evaporated in a rotary evaporator yielding crude oil, $300 \mu \mathrm{L}$ of the crude oil were pipetted into a transflectance cup of the spectrophotometer, and spectral readings were taken within a 1200-2400 nm interval. The spectra were then subjected to a local calibration model to define oleic and linoleic acid contents of the samples.

Data were analyzed with the SAS macro programming language developed by Bartolome and Gregorio (2000). Differences between genotypes for investigated traits were analyzed by the LSD test $(\mathrm{P} \leq 0.05)$. ANOVA was performed as outlined in Table 2 . Additive $\left(\sigma_{\mathrm{A}}^{2}\right)$ and dominance variance $\left(\sigma^{2} \mathrm{D}\right)$ were estimated with the inbreeding coefficient $(\mathrm{F})$ equal to 1 because both the lines and testers in this study were inbred. This macro also gives the general combining abilities

Table 2. ANOVA table for line $\times$ tester analysis.

\begin{tabular}{|c|c|c|c|c|}
\hline $\begin{array}{l}\text { Source } \\
\text { of variation }\end{array}$ & df & $\begin{array}{l}\text { Sum } \\
\text { of squares }\end{array}$ & $\begin{array}{c}\text { Mean } \\
\text { of squares }\end{array}$ & Expectations \\
\hline Replication & $r-1=2$ & $r S S$ & $r M S$ & $\ldots$ \\
\hline Genotype & $g-1=16$ & enSS & enMS & $\ldots$ \\
\hline $\mathrm{P} v s . \mathrm{H}$ & 1 & $\ldots$ & $\ldots$ & $\ldots$ \\
\hline Parent $(\mathrm{P})$ & $p-1=6$ & $p S S$ & $\ldots$ & $\ldots$ \\
\hline Cross $(\mathrm{C})$ & $\mathrm{c}-1=9$ & $c S S$ & $c M S$ & $\ldots$ \\
\hline Line (L) & $l-1=4$ & $l S S$ & $l M S$ & $\sigma_{\mathrm{e}}^{2}+r \operatorname{Cov}(F S)-2 \operatorname{Cov}(H S)+\operatorname{trCov}(H S)$ \\
\hline Tester (T) & $t-1=1$ & $t S S$ & $t M S$ & $\sigma_{\mathrm{e}}^{2}+r \operatorname{Cov}(F S)-2 \operatorname{Cov}(H S)+\operatorname{lr} \operatorname{Cov}(H S)$ \\
\hline Line $\times$ Tester & $(l-1)(t-1)=4$ & $l t S S$ & ltMS & $\sigma_{\mathrm{e}}^{2}+r \operatorname{Cov}(F S)-2 \operatorname{Cov}(H S)$ \\
\hline Error & $(g-1)(r-1)=32$ & $e S S$ & $e M S$ & $\sigma_{\mathrm{e}}^{2}$ \\
\hline
\end{tabular}

df: Degrees of freedom; $\operatorname{Cov}(\mathrm{FS})$ : full-sib covariance; $\operatorname{Cov}(\mathrm{HS})$ : half-sib covariance. 
(GCA) and specific combining abilities (SCA) of parents, and the mid-parent heterosis (MPH) values of crosses:

$$
\begin{aligned}
& \text { GCA lines }(l)=\mathrm{X}_{\mathrm{i}}-\mathrm{Y} \\
& \text { GCA tester }(t)=\mathrm{X}_{\mathrm{j}}-\mathrm{Y} \\
& \text { SCA }(l x t)=\mathrm{X}_{\mathrm{ij}}-\mathrm{X}_{\mathrm{i}}-\mathrm{X}_{\mathrm{j}}-\mathrm{Y}
\end{aligned}
$$

where $X_{i}$ is the mean of a cross with a given line (female) averaged over all replicates and testers (males), $X_{j}$ is the mean of the cross with a given tester (male) averaged over all replicates, years, locations, and lines (females), $\mathrm{X}_{\mathrm{ij}}$ is the mean of a given cross $(1 \times \mathrm{t})$ averaged over replicates, and $\mathrm{Y}$ is the experimental mean. The MPH values were calculated using mid-parent (MP) values and cross performance (HYB) as follows:

$$
\mathrm{MP}=(\mathrm{P} 1+\mathrm{P} 2) / 2, \mathrm{MPH}=[(\mathrm{HYB}-\mathrm{MP}) / \mathrm{MP}] \times 100
$$

Two different biplot analyses were performed in this study. The first was PCA biplot analysis applied with the numerical results of conventional $1 \times \mathrm{t}$ analysis with the BiplotGUI package of R software (La Grange et al., 2009). Center and scale transformation were applied to data and biplots were created separately for parents and crosses. Secondly, the GGE biplot method was applied with the GGEBiplotGUI package in R statistical software (Frutos et al., 2014).

Heterosis and gene action analysis were performed with polar plots (Lisec et al., 2011). These plots were generated with the $\mathrm{R}$ code obtained directly from Jan Lisec. Cross means and their parental values were entered into the $\mathrm{R}$ software ( $\mathrm{R}$ development Core Team, 2012), and the cross differences of their parents were then calculated. Mid-parent heterosis (MPH) values obtained from these calculations were transformed into degrees and radius to obtain more sensitive results. Polar plots were divided into 12 sections, and evaluations were made based on where the cross values are located in the plots. For more detailed information about this method see Lisec et al. (2011).

\section{RESULTS AND DISCUSSION}

Preliminary variance analysis showed there were significant differences between genotypes for all investigated traits.
Parents and crosses also showed significant differences in most investigated traits. However, female parents displayed no significant variation for protein and linoleic acid contents while the testers had no significant variation for single plant yield, oil content, or oleic and linoleic acid values (Table 3 ). In the current study, the $1 \mathrm{x}$ t effect consisted of the total sum of squares for single plant yield while the lines contributed a high degree of variation in the expression of other traits related to kernel quality (Table 3). These findings indicated that lines showed a large variation in kernel quality traits. Estimates of additive and dominance variance showed that all traits were inherited by non-additive gene action, except carotenoid content. This result agreed with previous studies suggesting a preponderance of non-additive gene action controlling kernel quality traits (Amit and Joshi, 2007) as well as kernel yield per plant (Saleem et al., 2002). However, some studies revealed that these traits were influenced by additive type gene action (Wattoo et al., 2009). These differences could be attributed to large differences between the parental lines of different studies.

Parental means ranged from 48.4 to $133.1 \mathrm{~g}, 9.6 \%$ to $21.7 \%, 3.33 \%$ to $14.5 \%, 3.03$ to $12.7 \mu \mathrm{g} \mathrm{g}^{-1}, 22.1 \%$ to $47.1 \%$, and $40.7 \%$ to $63.8 \%$ for single plant yield, and protein, oil, carotenoid, oleic acid, and linoleic acid contents, respectively. The superior parents in terms of genotype means and combining ability values were HYA, A680, and B73 for single plant yield; IHP, IHO, and B73 for protein content; IHO, HYA, and B73 for oil content; HYA, A680, Q2, and Mo17 for carotenoid content, all genotypes, except A680 and Mo17 for oleic acid, and A680 and Mo17 for linoleic acid. The cross means ranged from 137.7 to $248.0 \mathrm{~g}, 6.4 \%$ to $13.5 \%$, and $3.5 \%$ to $8.0 \%$ for single plant yield, protein content, and oil content, respectively. For single plant yield, $\mathrm{HYA} \times \mathrm{B} 73, \mathrm{IHP} \times \mathrm{B} 73$, and $\mathrm{A} 680 \times \mathrm{Mo} 17$ surpassed others in terms of cross means and SCA values (Table 5). For protein content, the superior crosses with high means and positive SCA values were HYA $\times$ B73, Q2 $\times$ Mo17, and $\mathrm{IHO} \times \mathrm{Mo17}$ (Table 5). The HYA $\times$ B73, IHO $\times$ Mo17, IHP $\times$ B73, and

\begin{tabular}{|c|c|c|c|c|c|c|c|}
\hline $\begin{array}{l}\text { Source } \\
\text { of variation }\end{array}$ & df & $\begin{array}{l}\text { Single plant } \\
\text { yield }\end{array}$ & $\begin{array}{l}\text { Protein } \\
\text { content }\end{array}$ & $\begin{array}{c}\text { Oil } \\
\text { content }\end{array}$ & $\begin{array}{c}\text { Carotenoid } \\
\text { content }\end{array}$ & $\begin{array}{c}\text { Oleic acid } \\
\text { content }\end{array}$ & $\begin{array}{c}\text { Linoleic } \\
\text { acid content }\end{array}$ \\
\hline Replication & 2 & 1791.9 & $0.52 * *$ & 0.39 & 11.08 & 0.53 & 2.77 \\
\hline Genotype & 16 & $134821.3^{* *}$ & $31.0 * *$ & $24.6 * *$ & $46.6 * *$ & $128.8 * *$ & $99.3 * *$ \\
\hline P vs. H & 1 & $87259.3 * *$ & $49.2 * *$ & $7.80 * *$ & $22.6^{*}$ & 6.50 & 0.81 \\
\hline Parent (P) & 6 & $18096.2 * *$ & $55.3 * *$ & $50.1 * *$ & $38.1 * *$ & $194.3 * *$ & $176.7 * *$ \\
\hline Cross (C) & 9 & $29465.7 * *$ & $12.8 * *$ & $9.04 * *$ & $55.0 * *$ & $98.7 * *$ & $58.7 * *$ \\
\hline Line & 4 & $5281.8 * *$ & 18.0 & $16.4 *$ & $110.2 * *$ & $190.7 *$ & 108.7 \\
\hline Tester & 1 & 6483.5 & $2.97 * *$ & 5.45 & $38.3 *$ & 3.31 & 1.45 \\
\hline Line $\times$ Tester & 4 & $17700.4 * *$ & $10.1 * *$ & $2.58 * *$ & 4.06 & $30.6 * *$ & $22.9 * *$ \\
\hline Error & 32 & 797.2 & 0.71 & 0.29 & 4.42 & 3.62 & 2.67 \\
\hline Contribution of lines & & 17.9 & 62.4 & 80.6 & 90.0 & 85.9 & 82.4 \\
\hline Contribution of testers & & 22.9 & 2.6 & 6.7 & 7.7 & 0.4 & 0.3 \\
\hline Contribution of $1 \times t$ & & 60.1 & 35.0 & 12.7 & 3.3 & 13.8 & 17.4 \\
\hline$\sigma^{2}{ }_{A}$ & & 163.9 & 0.09 & 0.30 & 2.44 & 2.89 & 1.48 \\
\hline$\sigma^{2}{ }_{D}$ & & 4837.2 & 12.5 & 3.06 & -0.47 & 40.0 & 26.9 \\
\hline$\sigma^{2}{ }_{A} / \sigma^{2} D$ & & 0.03 & 0.01 & 0.10 & -5.19 & 0.07 & 0.06 \\
\hline
\end{tabular}
$\mathrm{Q} 2 \times \mathrm{Mo} 17$ crosses were the best combinations for oil content (Table 5). Total carotenoid content in crosses varied between

Table 3. Mean squares in line $\times$ tester $(1 \times t)$ analysis for investigated traits.

*,**Significant at the 0.05 and 0.01 probability levels, respectively.

df: degrees of freedom; $\sigma^{2} \mathrm{~A}$ : additive variance; $\sigma^{2} \mathrm{D}$ : dominance variance. 
0.90 and $12.9 \mu \mathrm{g} \mathrm{g}^{-1}$. Oleic acid content varied from $25.9 \%$ to $46.5 \%$ while linoleic acid content varied between $44.9 \%$ and $59.6 \%$ (Table 5). Considering SCA values, the five crosses had positive values for carotenoid content as well as oleic and linoleic acids. Combinations generated by A680, HYA, and IHO female parents crossed with the B73 tester had positive values for linoleic acid content while their crosses with the Mo17 tester had negative values. A similar result was observed in combinations generated by IHP and Q2 female parents for oleic acid content (Table 5). Yield variation in parental means and combining ability values were similar to those of some previous studies while results for protein and oil contents were different (Balci et al., 2004; Werle et al., 2014). This result relied on the parents in our study (such as IHO, IHP, and HYA), which had higher values for protein and oil contents (Table 4). Total carotenoid content variation in our study was lower than the ones determined in earlier studies (de Almeida Rios et al., 2014). This is because we used white maize inbreds, such as IHO and IHP, in our study, which have lower kernel carotenoid content.

The other result obtained from conventional $1 \mathrm{x} t$ analysis was heterosis in crosses for observed traits. Five crosses $(\mathrm{HYA} \times \mathrm{B} 73$, $\mathrm{IHO} \times \mathrm{B} 73$, IHO $\times \mathrm{Mo17}, \mathrm{IHP} \times \mathrm{B} 73$, and IHP $\times$ Mo17) had positive heterosis for single plant yield, and two crosses (A680×B73 and Q2×Mo17) had positive heterosis for protein content. The crosses generated by A680 and Q2 showed positive heterosis for carotenoid content. Other crosses, except for the A680 parent combinations, had negative heterosis for oleic acid

Table 4. Means and general combining ability (GCA) values for investigated traits.

\begin{tabular}{|c|c|c|c|c|c|c|}
\hline \multirow[b]{2}{*}{ Parent } & \multicolumn{2}{|c|}{$\begin{array}{l}\text { Single plant } \\
\text { yield }(\mathrm{g})\end{array}$} & \multicolumn{2}{|c|}{$\begin{array}{c}\text { Protein } \\
\text { content }(\%)\end{array}$} & \multicolumn{2}{|c|}{$\begin{array}{c}\text { Oil } \\
\text { content }(\%)\end{array}$} \\
\hline & Mean & GCA & Mean & GCA & Mean & GCA \\
\hline A680 & $133.1 \mathrm{a}$ & 6.79 & $9.43 \mathrm{~d}$ & $-0.93^{* *}$ & $3.96 \mathrm{~cd}$ & $-1.92^{* *}$ \\
\hline HYA & $110.4 a-c$ & 15.9 & $13.7 b$ & $-1.81^{* *}$ & $8.97 b$ & $0.53^{* *}$ \\
\hline IHO & $62.4 \mathrm{de}$ & -5.59 & $12.7 b c$ & 0.58 & $14.5 \mathrm{a}$ & $2.52^{* *}$ \\
\hline IHP & $48.4 \mathrm{e}$ & 5.70 & $21.7 \mathrm{a}$ & $2.68^{* *}$ & $4.79 c$ & $-0.59^{* *}$ \\
\hline Q2 & $124.1 \mathrm{ab}$ & $-22.7^{*}$ & $9.60 d$ & -0.51 & $4.42 \mathrm{c}$ & $-0.53^{* *}$ \\
\hline B73 & $94.1 b-d$ & $14.7^{*}$ & $9.82 \mathrm{~d}$ & 0.31 & $3.87 \mathrm{~cd}$ & $0.42^{* *}$ \\
\hline Mo17 & $77.6 \mathrm{c}-\mathrm{e}$ & $-14.7^{*}$ & $11.8 \mathrm{c}$ & -0.31 & $3.33 \mathrm{~d}$ & $-0.42^{* *}$ \\
\hline $\operatorname{LSD}(5 \%)$ & 36.9 & & 1.74 & & 2.18 & \\
\hline SE $\left(G C A_{i}\right)$ lines & 8.15 & & 0.24 & & 0.156 & \\
\hline \multirow[t]{2}{*}{$\mathrm{SE}\left(G C A_{i}\right)$ testers } & 6.16 & & 0.18 & & 0.158 & \\
\hline & \multicolumn{2}{|c|}{$\begin{array}{c}\text { Carotenoid } \\
\text { content }\left(\mu \mathrm{g} \mathrm{g}^{-1}\right)\end{array}$} & \multicolumn{2}{|c|}{$\begin{array}{l}\text { Oleic acid } \\
\text { content }(\%)\end{array}$} & \multicolumn{2}{|c|}{$\begin{array}{l}\text { Linoleic acid } \\
\text { content }(\%)\end{array}$} \\
\hline Parent & Mean & GCA & Mean & GCA & Mean & GCA \\
\hline A680 & $3.03 \mathrm{e}$ & $5.14^{* *}$ & $47.1 \mathrm{a}$ & $-8.37^{* *}$ & $40.7 f$ & $7.22^{* *}$ \\
\hline HYA & $9.17 b$ & 0.73 & $37.8 \mathrm{c}$ & 0.07 & 46.6de & $-1.51^{* *}$ \\
\hline $\mathrm{IHO}$ & $3.72 \mathrm{de}$ & $-3.60^{* *}$ & $40.4 b$ & 0.62 & $45.8 \mathrm{e}$ & -0.90 \\
\hline IHP & $3.28 \mathrm{e}$ & $-5.06^{* *}$ & $34.8 \mathrm{e}$ & $7.52^{* *}$ & $50.8 \mathrm{c}$ & $-4.08^{* *}$ \\
\hline Q2 & $5.91 \mathrm{~cd}$ & $2.80^{* *}$ & $36.4 d$ & 0.17 & $48.2 \mathrm{~d}$ & -0.73 \\
\hline B73 & $6.64 c$ & -1.13 & $28.8 \mathrm{f}$ & 0.33 & $56.7 \mathrm{~b}$ & -0.22 \\
\hline Mo17 & $12.7 \mathrm{a}$ & 1.13 & $22.1 \mathrm{~g}$ & -0.33 & $63.8 \mathrm{a}$ & 0.22 \\
\hline LSD (5\%) & 2.43 & & 1.26 & & 1.63 & \\
\hline SE $\left(G C A_{i}\right)$ lines & 0.61 & & 0.55 & & 0.47 & \\
\hline $\mathrm{SE}\left(G C A_{i}\right)$ testers & 0.46 & & 0.42 & & 0.36 & \\
\hline
\end{tabular}

\footnotetext{
* , ${ }^{* *}$ Significant at the 0.05 and 0.01 probability levels, respectively. Different lowercase letters indicate significant differences according to LSD test $(\mathrm{P}<0.05)$ between genotypes.

$\mathrm{SE}\left(\mathrm{GCA}_{\mathrm{i}}\right)$ lines: standard error for GCA effects for lines.

$\mathrm{SE}\left(\mathrm{GCA}_{\mathrm{i}}\right)$ testers: standard error for GCA effects for testers
}

content but had positive values for linoleic acid content (Table 5). In previous studies, positive heterosis was also reported for yield; however, negative or no heterosis was found for oil and protein contents (Bekele and Rao, 2013). Our results concur with findings of previous research for yield although they are different for oil, protein, and oleic acid contents. This result was related to using particular parents (i.e., high protein and high oil) in our study (Table 1).

Results of the PCA biplot representation are shown in Figure 1. This figure summarizes the GCA values of parents (Figure 1a, 1b) and SCA values of crosses (Figure 1c, 1d). The PCA biplots explain most of the variation in the observed traits where $74.3 \%, 92.3 \%, 77.8 \%$, and $78.6 \%$ of total variation are explained in Figures 1a, 1b, 1c, and 1d, respectively. Regarding PCA biplots, the best female parents were A680 and Q2 for yield, IHO and HYA for oil content, and IHP for protein content (Figure 1a). Testers showed higher values for carotenoid and linoleic acid content compared to female lines. The A680, IHO, and IHP lines had high mean values for oleic acid content; IHO and IHP also had positive GCA for this component (Figure 1b). The $\mathrm{HYA} \times \mathrm{B} 73$, IHO $\times \mathrm{Mo17}, \mathrm{A} 680 \times \mathrm{Mo17}$, and $\mathrm{IHP} \times \mathrm{B} 73$ crosses had both high mean and positive SCA values for yield and protein content. The $\mathrm{IHO} \times \mathrm{B} 73$ and $\mathrm{IHO} \times \mathrm{Mo} 17$ crosses had high oil content; however, the $\mathrm{HYA} \times \mathrm{B} 73$ cross had the highest positive SCA value (Figure 1c). The IHP $\times$ B73 cross was the best for oleic acid and $A 680 \times B 73$ was the best for linoleic acid. The A680×Mo17 cross showed the best performance with the highest mean and positive SCA values for carotenoid content (Figure 1d). The Q2 $\times$ B 73, A680 $\times$ Mo17, HYA $\times$ Mo17, IHO $\times$ Mo17, and $\mathrm{IHP} \times \mathrm{B} 73$ crosses had positive SCA values for oleic acid while other crosses had positive SCA for linoleic acid (Figure 1d).

Both mid-parent heterosis values, and mean performance are summarized by PCA biplots in Figures 1e and 1f. The PCA biplots showed that the $\mathrm{IHP} \times \mathrm{B} 73$ and $\mathrm{HYA} \times \mathrm{B} 73$ crosses had high mean values for yield and protein content. These crosses also showed positive heterosis for yield. Positive heterosis values were observed for oil and protein contents in the Q2 $\times$ Mo17 and Q2 $\times$ B73 crosses (Figure 1e). Carotenoid content was higher in crosses generated from A680 and Q2 lines. Crosses generated from A680 had positive heterosis values for linoleic acid while the other crosses had positive heterosis for oleic acid (Figure 1e). Results from PCA biplot analysis were very similar to those from conventional analysis (Table 4). Thus, we can say that the PCA biplot is a good choice to represent graphically the heterosis analysis results. This method not only enabled the presentation of MPH values for observed traits but also exhibited the superior cross combinations.

Figure 2 shows the GGE biplot outputs that were obtained using the mean vs. stability option. Most of the variation is explained by the first principal component in the GGE biplot analyses. It explained 81.79\%, 76.61\%, 86.57\%, 99.29\%, $93.95 \%$, and $89.49 \%$ of the total variation in yield, and protein, oil, carotenoid, oleic acid, and linoleic acid contents, respectively (Figure 2). 
Table 5. Means, specific combining ability (SCA), and mid-parent heterosis (MPH) values for investigated traits.

\begin{tabular}{|c|c|c|c|c|c|c|c|c|c|}
\hline \multirow[b]{2}{*}{ Cross } & \multicolumn{3}{|c|}{ Single plant yield (g) } & \multicolumn{3}{|c|}{ Protein content $(\%)$} & \multicolumn{3}{|c|}{ Oil content (\%) } \\
\hline & Mean & SCA & $\mathrm{MPH}$ & Mean & SCA & $\mathrm{MPH}$ & Mean & SCA & $\mathrm{MPH}$ \\
\hline A $680 \times B 73$ & $171.2 \mathrm{bc}$ & -27.20 & 50.7 & $10.10 \mathrm{~cd}$ & 0.02 & 4.62 & $3.57 \mathrm{de}$ & -0.39 & -8.60 \\
\hline A680×Mo17 & $196.2 \mathrm{ab}$ & 27.20 & 86.3 & $9.40 \mathrm{~d}$ & -0.02 & -11.50 & $3.51 \mathrm{e}$ & 0.39 & -3.54 \\
\hline HYA×B73 & $248.0 \mathrm{a}$ & 40.40 & 142.4 & $11.30 \mathrm{~b}$ & $2.14^{* *}$ & -3.65 & $7.52 \mathrm{a}$ & $1.09^{* *}$ & 17.20 \\
\hline HYA×Mo17 & $137.7 \mathrm{c}$ & -40.40 & 46.4 & $6.40 \mathrm{e}$ & $-2.14^{* *}$ & -49.70 & $4.47 \mathrm{~cd}$ & $-1.09^{* *}$ & -27.20 \\
\hline $\mathrm{IHO} \times \mathrm{B} 73$ & $164.0 \mathrm{bc}$ & -22.10 & 109.4 & $10.90 b c$ & -0.69 & -3.43 & $8.02 \mathrm{a}$ & -0.39 & -12.70 \\
\hline IHO×Mo17 & $178.7 \mathrm{bc}$ & 22.10 & 155.3 & $11.60 \mathrm{~b}$ & 0.68 & -5.20 & $7.95 \mathrm{a}$ & 0.39 & -10.80 \\
\hline IHP×B73 & $206.6 a b$ & 9.22 & 189.7 & $13.50 \mathrm{a}$ & -0.21 & -14.40 & $5.43 b$ & 0.12 & 25.30 \\
\hline IHP×Mo17 & $158.7 b c$ & -9.22 & 151.8 & $13.30 \mathrm{a}$ & 0.21 & -20.80 & $4.32 \mathrm{c}-\mathrm{e}$ & -0.12 & 6.26 \\
\hline Q2×B73 & $168.5 b c$ & -0.36 & 54.4 & $9.21 d$ & -1.27 & -5.13 & $4.92 b c$ & -0.44 & 18.70 \\
\hline $\mathrm{Q} 2 \times \mathrm{Mo} 17$ & $139.8 \mathrm{c}$ & 0.36 & 38.6 & $11.10 \mathrm{bc}$ & 1.27 & 3.94 & $4.94 b c$ & 0.44 & 27.60 \\
\hline $\operatorname{LSD}(5 \%)$ & 53.8 & & & 1.24 & & & 0.92 & & \\
\hline \multirow[t]{2}{*}{$\mathrm{SE}\left(S C A_{i j}\right)$ crosses } & 16.3 & & & 0.49 & & & 0.31 & & \\
\hline & \multicolumn{3}{|c|}{ Carotenoid content $\left(\mu \mathrm{g} \mathrm{g}^{-1}\right)$} & \multicolumn{3}{|c|}{ Oleic acid content (\%) } & \multicolumn{3}{|c|}{ Linoleic acid content (\%) } \\
\hline Cross & Mean & SCA & $\mathrm{MPH}$ & Mean & SCA & $\mathrm{MPH}$ & Mean & SCA & $\mathrm{MPH}$ \\
\hline $\mathrm{A} 680 \times \mathrm{B} 73$ & $12.70 \mathrm{a}$ & 1.03 & 163.60 & $25.9 \mathrm{f}$ & -2.15 & -31.80 & $59.6 \mathrm{a}$ & 1.98 & 22.30 \\
\hline A680×Mo17 & $12.90 \mathrm{a}$ & -1.03 & 64.50 & $29.5 \mathrm{ef}$ & 2.15 & -14.70 & $56.1 \mathrm{~b}$ & -1.98 & 7.37 \\
\hline HYA×B73 & $6.80 \mathrm{bc}$ & -0.50 & -13.90 & $34.8 \mathrm{~cd}$ & -1.66 & 4.50 & $50.2 \mathrm{~cd}$ & 1.31 & -2.84 \\
\hline HYA×Mo17 & $10.10 \mathrm{ab}$ & 0.50 & -8.07 & $37.5 b-d$ & 1.66 & 25.20 & $48.0 \mathrm{de}$ & -1.31 & -12.90 \\
\hline $\mathrm{IHO} \times \mathrm{B} 73$ & $2.30 \mathrm{~d}$ & -0.67 & -55.60 & $35.9 \mathrm{~cd}$ & -1.07 & 3.91 & $50.3 \mathrm{~cd}$ & 0.79 & -1.88 \\
\hline $\mathrm{IHO} \times \mathrm{Mo} 17$ & $5.91 \mathrm{c}$ & 0.67 & -28.10 & $37.4 \mathrm{~b}-\mathrm{d}$ & 1.07 & 19.90 & $49.2 d$ & -0.79 & -10.30 \\
\hline IHP×B73 & $0.90 \mathrm{~d}$ & -0.61 & -81.90 & $46.5 \mathrm{a}$ & 2.56 & 46.00 & $44.9 \mathrm{e}$ & -1.48 & -16.60 \\
\hline IHP×Mo17 & $4.38 \mathrm{~cd}$ & 0.61 & -45.20 & $40.7 b$ & -2.56 & 43.00 & $48.3 \mathrm{de}$ & 1.48 & -15.60 \\
\hline Q2×B73 & $10.10 \mathrm{ab}$ & 0.76 & 61.50 & $38.9 b c$ & 2.31 & 19.20 & $47.1 \mathrm{de}$ & -2.61 & -10.30 \\
\hline Q2×Mo17 & $10.90 \mathrm{a}$ & -0.76 & 16.80 & 33.6de & -2.31 & 14.80 & $52.7 \mathrm{bc}$ & 2.61 & -5.82 \\
\hline $\mathrm{LSD}(5 \%)$ & 3.56 & & & 4.22 & & & 3.48 & & \\
\hline $\mathrm{SE}\left(S C A_{i j}\right)$ crosses & 1.21 & & & 1.10 & & & 0.94 & & \\
\hline
\end{tabular}

${ }^{*},{ }^{* *}$ Significant at the 0.05 and 0.01 probability levels, respectively.

Different lowercase letters indicate significant differences according to LSD test $(\mathrm{P}<0.05)$ between genotypes.

$\mathrm{SE}\left(S C A_{i j}\right)$ crosses: standard error for SCA effects for crosses.

Three components were used when presenting the combining abilities of the genotypes in the GGE biplot methodology. The first is the average tester coordinate (ATC), the second is the ATC abscissa, and the third is the ATC ordinate. The ATC is a virtual tester shown as a small circle in the GGE biplot diagram. The ATC abscissa is shown as a thick arrowhead line in the GGE biplot diagram, and it differentiates the average tester from the biplot origin. The ATC ordinate is a double-arrowhead line positioned vertically with the ATC abscissa (Yan and Hunt, 2002). The GCA effects of the parental lines were evaluated by an arrow on the ATC ordinate while the SCA effects are investigated by projecting an ATC ordinate from the biplot origin (Yan, 2001). If the tester is positioned on the right side of an ATC ordinate, it is considered as having positive GCA values. If it is positioned on the left side of the ATC ordinate, it is accepted that the tester has a negative GCA value for the analyzed trait in GGE biplot methodology (Yan, 2001).

In our study, the best female parents were HYA, A680, and IHP for yield and IHO and IHP for protein, IHO and HYA for oil, A680, Q2, and HYA for carotenoid, IHP and IHO for oleic, and A680 for linoleic acid contents. The B73 tester was the best combiner for the four investigated traits, except for oleic and linolenic acid content. The Mo17 tester hada better performance for oleic and linolenic acid contents (Figure 2). Projecting the lines to the ATC ordinate and its position on the GGE biplots indicated the SCA values of the crosses. The best cross combinations were HYA $\times$ B 73 and $\mathrm{A} 680 \times \mathrm{Mo} 17$ for yield, $\mathrm{IHO} \times \mathrm{Mo} 17$ and $\mathrm{IHP} \times \mathrm{B} 73$ for protein, $\mathrm{IHO} \times \mathrm{Mo} 17$ and $\mathrm{HYA} \times \mathrm{B} 73$ for oil, $\mathrm{HYA} \times \mathrm{Mo17}$, $\mathrm{A} 680 \times \mathrm{B} 73$, and $\mathrm{Q} 2 \times \mathrm{B} 73$ for carotenoid, $\mathrm{IHO} \times \mathrm{Mo17}$, $\mathrm{HYA} \times \mathrm{Mo} 17$, and $\mathrm{Q} 2 \times \mathrm{B} 73$ for oleic acid, and $\mathrm{A} 680 \times \mathrm{Mo} 17$ and $\mathrm{A} 380 \times \mathrm{B} 73$ for linoleic acid contents. Both GCA and SCA results were similar to the results from conventional analysis (Tables 4 and 5).

Previous research has shown that the polygon view of GGE biplots enabled classifying genotypes according to their heterotic group (Fotokian and Agahi, 2014). We did not take this view because our study aimed to show the potential for presenting results from conventional analysis by graphical analysis. Although the GGE biplot offered such an additional opportunity, this method could not provide the opportunity for heterosis analysis in conventional analysis. From this standpoint, we can speculate that for heterosis and gene action analysis, GGE biplot analysis exhibits an important disadvantage.

Polar plot is an advanced method for visualizing heterosis and gene actions. Positive heterosis was observed for plant yield, and overdominant gene action appears to play a role in changing this trait (Figure 3a). Oil and protein content were lower in crosses than in their parental means. Although additive type gene actions generally play a major role in changing these traits, only one cross was negative over the dominant gene action (Figure 1a). This result is consistent with the result of conventional analysis (Table 2). Crosses 
Figure 1. Principal component analysis (PCA) biplot diagrams for parents (a, b) and crosses (c, d) representing means and combining abilities. Heterosis and mean values for crosses shown in separate diagrams $(e, f)$.
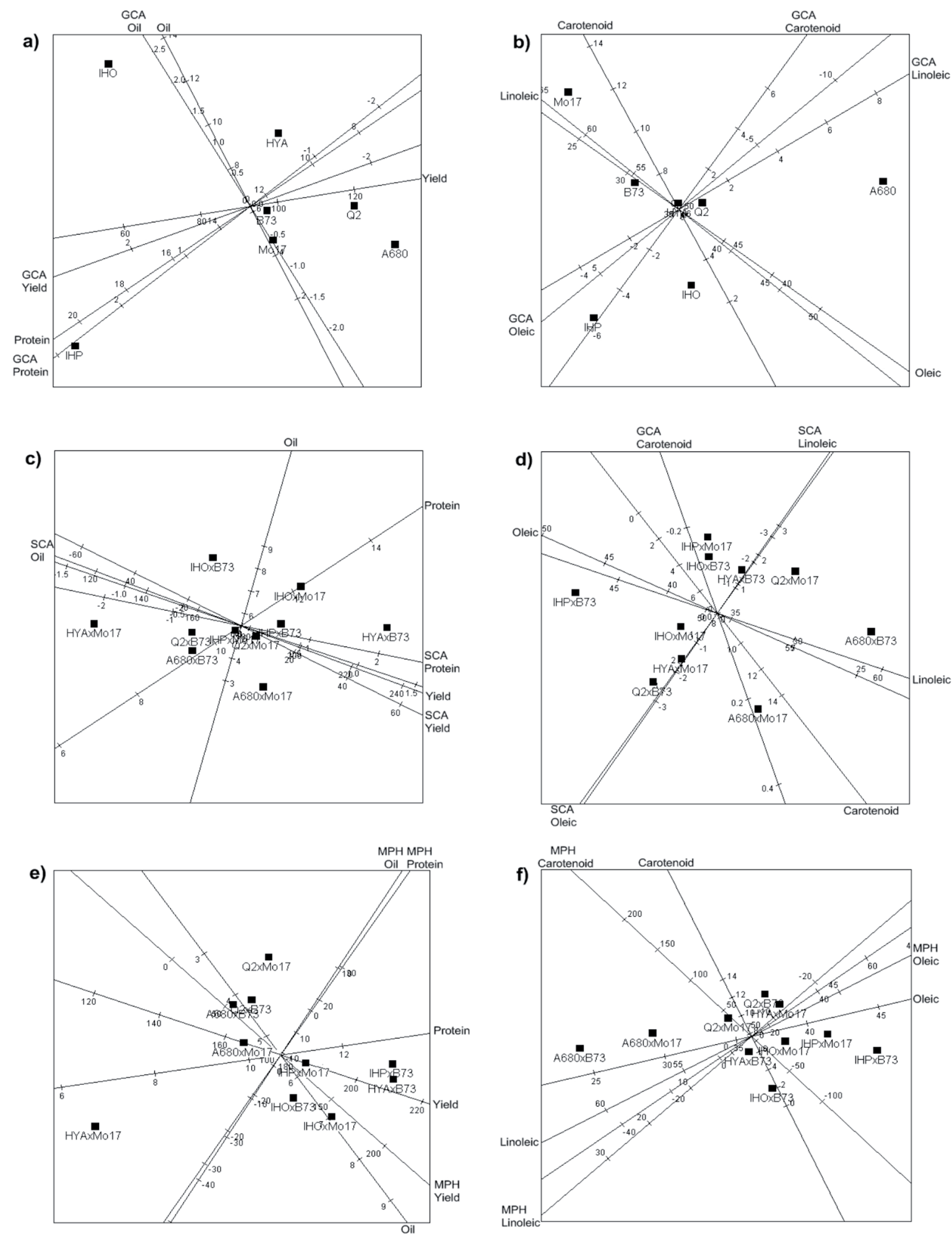

GCA: general combining ability; SCA: specific combining ability; MPH: mid-parent heterosis. 
Figure 2. Genotype + genotype $x$ environment (GGE) biplot outputs for yield (a), protein content (b), oil content (c), carotenoid content (d), oleic acid ratio (e), and linoleic acid ratio (f). Plotting parameters were Transform $=0, \mathrm{Scaling}=0, \mathrm{Centered}=2, \mathrm{SVP}=2$.
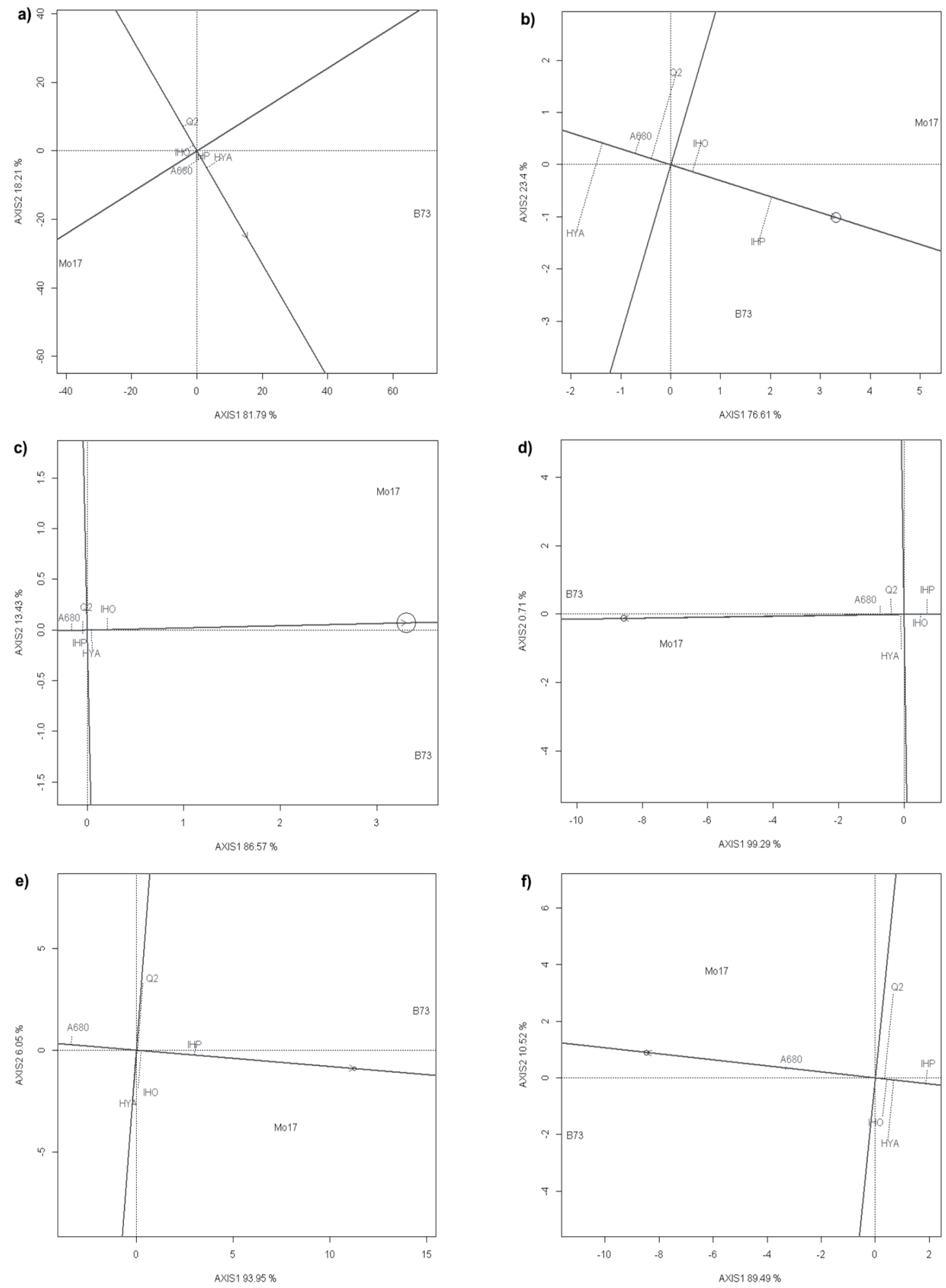
Figure 3. Polar plots for yield, protein content, and oil content (a); carotenoid content, oleic acid content, and linoleic acid content (b).
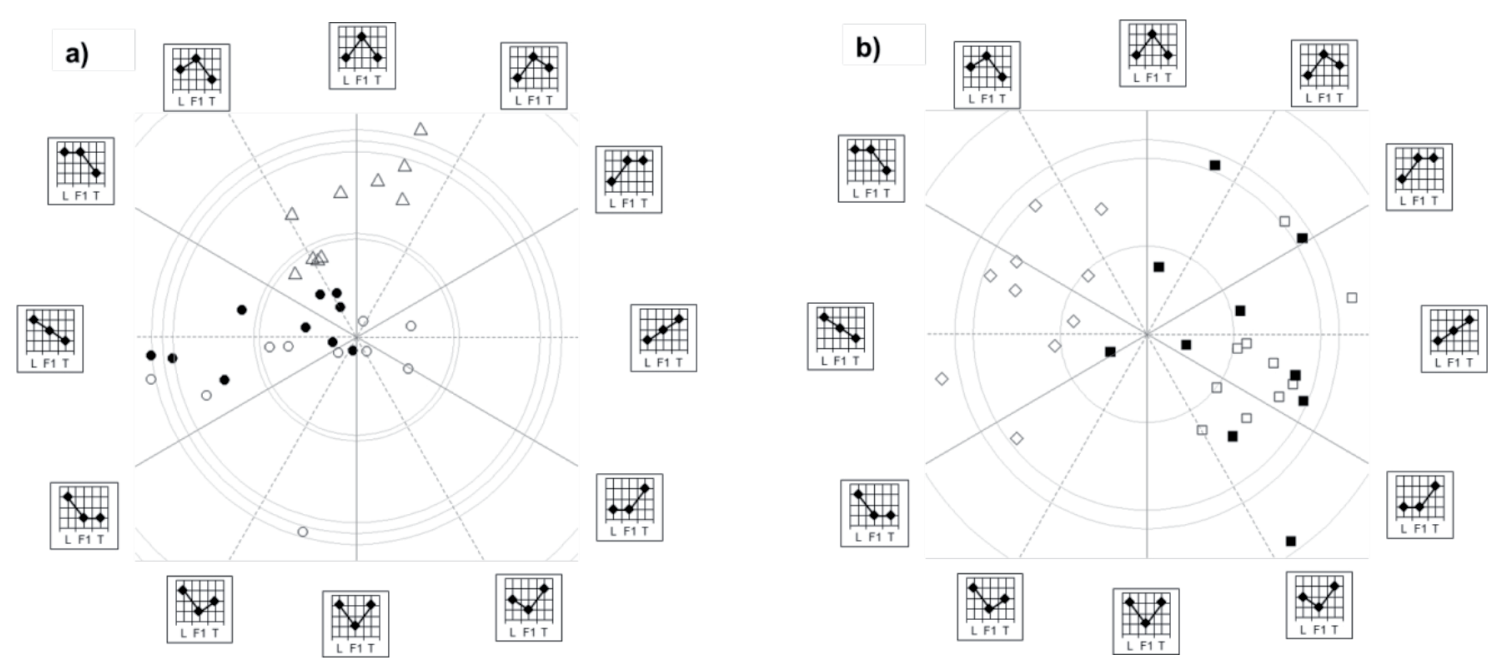

In these plots, null triangles, filled circles, null circles, filled squares, null triangles, and null squares indicate yield, and oil, protein, carotenoid, oleic acid, and linoleic acid contents, respectively.

$\mathrm{L}$ : line, $\mathrm{F}_{1}$ : cross, $\mathrm{T}$ : tester.

performed better for oleic acid than tester lines; however, they had higher values than their female parents and lower values than the tester lines (Figure 3b). It cannot be said that there was any obvious type of gene action for these mentioned traits. However, we speculated that dominant and additive type gene actions played a more prominent role in changing these traits (Figure 3b). Previous findings also showed that yield was controlled by dominant gene actions in maize (Unay et al., 2004) while kernel quality traits, such as protein and oil contents, were mainly controlled by additive effects (Rosulj et al., 2002; Wattoo et al., 2009). The number of crosses with positive or negative heterosis values can be seen in the polar plots, which is the main advantage of this method. Additionally, this method clearly showed the differences between crosses and their parents (male or female). The main disadvantage of this method was that cross names were not seen in the plots. This problem can be solved by making changes in the macro of the polar plots where studies can be arranged with a small number of crosses. In studies with a high number of crosses, only outlier crosses can be named.

\section{CONCLUSION}

We found that the best parents were A680 and HYA for single plant yield, IHP for protein content, IHO and HYA for oil content, A680 and Q2 for carotenoid content, IHP for oleic acid content, and A680 for linoleic acid content. The HYA $\times$ B73 cross can be introduced into the cross breeding program with multipurpose objectives to improve both yield and main quality traits, such as oil and protein contents. We made a detailed comparison of different graphical techniques in terms of their potential and ability to present the results of a maize breeding experiment. The advantages and disadvantages of the graphical methods should be considered for their potential use in breeding experiments. The principal component analysis (PCA) biplot method has an important advantage because it can simultaneously present the means and combining abilities of the investigated traits. The GGE biplot methodology is only able to show the combining abilities of the breeding materials; however, its main advantage is the possibility of inputting raw data into an analysis program. In the PCA biplot method, conventional analysis was performed and the results were then inputted into a special package of analysis software. From this standpoint, the PCA biplot should be considered as a representative method, not as genetic analysis methodology. The other weakness of the PCA biplot method is the difficulty of presenting all the variations when the means and combining abilities are shown together.

In conclusion, it can be inferred that biplot methodologies can be used for evaluating parents and crosses in a line $x$ tester design. These methodologies provide easily understandable outputs. The PCA biplot method can be used alone or the genotype + genotype $\times$ environment (GGE) biplot method can be used together with polar plots for analyzing/representing data obtained from breeding experiments.

\section{ACKNOWLEDGEMENTS}

The authors acknowledge the assistance of graduate students in the Field Crops Department at Çanakkale Onsekiz Mart University, Turkey, for their efforts in helping to carry out the field experiment and laboratory studies. We also thank to Dr. Violeta Bartolome and Dr. Jan Lisec for providing us with the program codes used in this paper. 


\section{REFERENCES}

Amin, M.N., M. Amirurzaman, A. Ahmed, and M.R. Ali. 2014. Evaluation of inbred lines of maize (Zea mays L.) through line $\times$ tester method. Bangladesh Journal of Agricultural Research 39(4):675-683.

Amit, D., and V.N. Joshi. 2007. Heterosis and combining ability for quality and yield in early maturing single cross hybrids of maize (Zea mays L.) Indian Journal of Agricultural Research 41(3):8240-8245.

Badu-Apraku, B., M. Oyekunle, M.A.B. Fakorede, I. Vroh, R.O. Akinwale, and M. Aderounmu. 2013. Combining ability, heterotic patterns and genetic diversity of extra-early yellow inbreds under contrasting environments. Euphytica 192:413-433.

Balci, A., I. Turgut, and A. Duman. 2004. A Research on determination of superior hybrids combinations in corn (Zea mays indentata Sturt.) Anadolu 14(2):1-15.

Bartolome, V.I., and G.B. Gregorio. 2000. An interactive macro program for Line $\times$ Tester analysis. $25^{\text {th }}$ SAS Conference Proceedings, Indianapolis. 9-12 April 2000. SAS Users Group International, Indianapolis, Indiana, USA.

Bekele, A., and T.N. Rao. 2013. Heterosis study for grain yield, protein and oil improvement in selected genotypes of maize (Zea mays L.) Journal of Plant Science 1(4):57-63.

de Almeida Rios, S., M.C.D. Paes, W.S. Cardoso, A. Borém, and F.F. Teixeira. 2014. Color of corn grains and carotenoid profile of importance for human health. American Journal of Plant Sciences 5:857-862.

Egesel, C.O., F. Kahriman, and N. Corbacioglu. 2013. The effects of generation and parents on endosperm protein ratio and change of protein fractions in maize. Anadolu Journal of Agricultural Sciences 28(3): 150-156.

Egesel, C.O., F. Kahriman, and M.K. Gul. 2011. Discrimination of maize inbreds for kernel quality traits and fatty acid composition by a multivariate technique. Acta Scientiarum Agronomy Maringá 33(4):613-620.

Elmyhum, M. 2013. Estimation of combining ability and heterosis of quality protein maize inbred lines. African Journal of Agricultural Research 8(48):6309-6317.

Fotokian, M.H., and K. Agahi. 2014. Biplot analysis of genotype by environment for cooking quality in hybrid rice: A tool for Line $x$ Tester data. Rice Science 21(5):282-287.

Frutos, E., M.P. Galindo, and V. Leiva. 2014. An interactive biplot implementation in $\mathrm{R}$ for modeling genotype-by-environment interaction. Stochastic Environmental Research and Risk Assessment 28:1627-1641.

La Grange,A., N. Le Roux, and S. Gardner-Lubbe. 2009. BiplotGUI: Interactive Biplots in R. Journal of Statistical Software 30:1-37.

Langade, D.M., J.P. Shahi, V.K. Agrawal, and A. Sharma. 2013. Maize as emerging source of oil in India: an overview. Maydica 58:224-230.

Lisec, J., L. Romisch-Margl, Z. Nikoloski, H.P. Piepho, P. Giavalisco, J. Selbig, et al. 2011. Corn hybrids display lower metabolite variability and complex metabolite inheritance patterns. Plant Journal 68:326-336.

Mahesh, N., M.C. Wali, M.V.C. Gowda, B.N. Motagi, and N.F. Uppinal. 2013. Genetic analysis of grain yield, starch, protein, and oil content in single cross hybrids of maize. Kartanaka Journal of Agricultural Sciences 26(2):185-189.
Mittelmann, A., J.B.C. de Miranda Filho, G.J.M.M. de Lima, C. Hara-Klein, and R.T. Tanaka. 2003. Potential of the ESA23B Maize population for protein and oil content improvement. Scientia Agricola 60(2):319-327.

Mostavi, K., R. Choukhan, M. Taeb, E.M. Heravan, and M.R. Bihatma. 2012. Heterotic grouping of Iranian maize inbred lines based on yield-specific combining ability in diallel crosses and GGE biplot. Journal of Research in Agricultural Science 8:113-125.

Nduwumuremyi, A., P. Tongoona, and S. Habimana. 2013. Mating design: Helpful tool for quantitative plant breeding analysis. Journal of Plant Breeding and Genetics 1(3):117-129.

Ozcan, S. 2009. Corn, indispensable crop of the modern world: Contribution of genetically modified (transgenic) corn on agricultural production. Turkish Journal of Scientific Reviews 2(2):1-34.

Pollak, L., and M.P. Scott. 2005. Breeding for grain quality traits. Maydica 50:247-257.

R Development Core Team. 2012. R: A language and environment for statistical computing. R Foundation for Statistical Computing, Vienna, Austria. Available at http://www.R-project.org (accessed September 2015).

Rodriguez-Amaya, D.B., and M. Kimura. 2004. HarvestPlus handbook for carotenoid analysis. HarvestPlus Technical Monograph Series 2. IFPRI, Washington, D.C., USA, and CIAT, Cali, Colombia.

Rosulj, M., S. Trifunovic, and I. Husic. 2002. Nine cycles of mass selection for increasing oil content in two maize (Zea mays L.) synthetics. Genetics and Molecular Biology 25(4):449-461.

Ruswandi,D., J. Suprianta, B. Waluyo,A.T.Makkulawu,E. Suryandi, Z.U.Chindy, et al. 2015. GGE Biplot analysis for combining ability of grain yield and early maturity in maize mutant in Indonesia. Asian Journal of Crop Science 7(3):160-173.

Saleem, M., K. Shahzad, M. Javid, and A. Ahmed. 2002. Genetic analysis for various quantitative traits in maize (Zea mays L.) inbred lines. International Journal of Agriculture and Biology 4(3):379-382.

Sharma, J.R. 2006. Statistical and biometrical techniques in plant breeding. 432 p. New Age International, New Delhi, Delhi, India.

Turgut, I. 2003. Determination of combining ability effects and heterosis by line $\times$ tester analysis method in maize (Zea mays indentata Sturt.) Journal of Agricultural Faculty of Uludağ University 17(2):33-46.

Unay, A., H. Basal, and C. Konak. 2004. Inheritance of grain yield in a half-diallel maize population. Turkish Journal of Agriculture and Forestry 28:239-244.

Wattoo, F.M., M. Saleem, M. Ahsan, M. Sajjad, and W. Ali. 2009. Genetic analysis for yield potential and quality traits in maize (Zea mays L.) American-Eurasian Journal of Agriculture Environment Science 6(6):723-729.

Werle, A.J.S., F.R.A. Ferreira, R.J.B. Pinto, C.A. Mangolin, C.A. Scapim, and L.S.A. Gonçalves. 2014. Diallel analysis of maize inbred lines for grain yield, oil and protein content. Crop Breeding and Applied Biotechnology 14:23-28.

Yan, W.K. 2001. GGEbiplot: A windows application for graphical analysis of multienvironment trial data and other types of twoway data. Agronomy Journal 93:1111-1118.

Yan, W.K., and L.A. Hunt. 2002. Biplot analysis of diallel data. Crop Science 42:21-30. 